\title{
Pembekalan Karakter Bagi Guru TPQ-TPA Fosi Kecamatan Taman Kota Madiun
}

\author{
Wuryantoro \\ Prodi Agroteknologi, Universitas Merdeka Madiun, Jl. Serayu No.79, Madiun, 63133 \\ E-mail: wuryantoro@unmer-madiun.ac.id
}

\begin{abstract}
There are about 10 indicators of low social capital and character among the younger generation to worry about, namely increased teenage violence, poor use of language and words, strong peer group influence on violence, increased selfdestructive behavior such as drugs, alcohol, free sex, the blurring of good and bad moral guidelines, the decline in work ethic, the lower respect for parents, the low individual responsibility for the country and the mutual suspicion of hatred among others. Academic pressure on the current education system is considered to be responsible for these problems, so that it requires the teacher to revitalize himself from a teacher who merely conveys the knowledge of being an educator who must be responsible for instilling morals. Lack of moral education, can make the brain stem and midbrain which is often called the reptile brain, more developed and dominant and makes someone will tend to behave violently. While the limbic and cortex parts of the brain that determine emotions, love and thinking become thin and weak. Conversely, if the limbic and cortex are dominant, reason and empathy will develop and become someone who is wise and wise. For all education and childcare are the main determining factors, which must be understood by educators (teachers, "ustadz”) and parents.
\end{abstract}

Keywords—: Character; educator; parents; social capital.

\section{PENDAhuluan}

Hasil kajian membuktikan bahwa kunci sukses suatu negara ditentukan karakter yang kondusif sebagai "modal sosial" yang dapat mengalahkan modal intelektual yang mendominasi bangku akademis saat ini. Negara-negara yang sekarang telah memperoleh kemajuan bukanlah semuanya negara dengan kekayaan sumberdaya alam melimpah, namun mereka mempunyai modal sosial karakter yang bagus. Modal tersebut adalah rasa kebersamaan tinggi, rasa saling percaya (vertikal-horizontal), rendahnya tingkat konflik, loyalitas/nasionalisme, kejujuran dan kerja keras. Saat ini, ada 10 indikator karakter generasi muda yang patut dicemaskan : meningkatnya kekerasan remaja, penggunaan bahasa dan kata2 yang buruk,pengaruh peer group yg kuat untuk kekerasan, perilaku merusak diri meningkat seperti narkoba, alkohol, sex bebas, semakin kaburnya pedoman moral baik dan buruk, menurunnya etos kerja, semakin rendah rasa hormat pada orang tua, rendahnya tanggung jawab individu kpd negara serta adanya rasa saling curiga da kebencian di antara sesama (Lickona T, 2012). Tekanan akademis pada sistem pendidikan saat ini, dinilai bertanggung jawab atas permasalah tersebut, sehingga mengharuskan tokoh guru merevitalisasi diri dari seorang pengajar yang hanya sekedar menyampaikan ilmu menjadi seorang pendidik yang harus bertanggung jawab menanamkan akhlak. Kurangnya pendidikan akhlak, dapat menjadikan "batang otak" (brain stem) dan "otak tengah" yang sering disebut otak reptil, lebih berkembang dan dominan dan menjadikan seseorang akan cenderung berperilaku kekerasan. Sedangkan bagian otak "limbic" dan "korteks" yang menentukan emosi, cinta dan berpikir menjadi tipis dan lemah. Sebaliknya apabila bagian limbik dan korteks ini dominan maka akal dan empati akan berkembang dan menjadi seseorang yang arif dan bijaksana. Untuk semuanya pendidikan dan pengasuhan anak menjadi faktor penentu utama, yang harus dipahami oleh pendidik (guru dan dosen) dan orang tua. Ada dua faktor yang mempengaruhi pembantukan karakter, yaitu bawaan dari dalam diri anak dan pandangan anak terhadap dunia yang dimilikinya, seperti pengetahuan, pengalaman, prinsip-prinsip moral yang diterima, bimbingan, pengarahan dan interaksi (hubungan) orangtua-anak.

Lingkungan yang positif akan membentuk karakter yang positif pula pada anak. Salah satu contoh kisah nyata, seorang anak laki-laki dibesarkan dalam lingkungan binatang. Si anak berjalan dengan merangkak, makan, bertingkah laku, dan bersuara seperti binatang karena ia tidak bisa bicara. Orang yang menemukan si anak berusaha mendidiknya kembali seperti halnya anak-anak pada umumnya. Hasilnya, si anak tetap memiliki pribadi seperti binatang karena sebagian besar hidupnya dilalui bersama binatang sejak usia dini. Tampak di sini betapa besar pengaruh lingkungan terhadap pembentukan karakter. Dari contoh tersebut dapat ditarik kesimpulan bahwa karakter seseorang tidak hanya dipengaruhi oleh bawaan, tetapi juga lingkungan (terutama, dalam keluarga) memiliki pengaruh yang sangat besar.

Karakter berhubungan dengan perilaku positif yang berkaitan dengan moral yang berlaku, seperti kejujuran, percaya diri, bertanggung jawab, penolong, dapat dipercaya, menghargai, menghormati, menyayangi, dan sebagai-nya. Pada dasarnya, setiap anak memiliki semua

perilaku positif tersebut, seba-gaimana telah ditanamkan oleh Sang Pencipta di dalam kodratnya. Masalahnya, kemampuan dasar yang terdapat di dalam diri anak itu tidak bisa berkembang dengan sendirinya, melainkan harus dikembangkan dengan sungguh-sungguh melalui pengasuhan dan bimbingan yang positif dari ibu- ayah. Jika setiap anak dan keluarga memiliki 
Website : http://dayamas.unmermadiun.ac.id/index.php/dayamas

karakter positif, maka akan tercipta masyarakat dengan moral yang baik, sehingga akan tercipta pula bangsa yang dapat hidup rukun sesuai dengan aturan-aturan yang berlaku.

Apresiasi penulis sampaikan kepada Yayasan IHF yang banyak menginspirasi penulis. Forum silaturahim (Fosi) Guru TPQTPA kecamatan Taman Kota Madiun merupakan lembaga yang membawahi guru lebih dari 30 TPQ-TPA se wiayah Kecamatan Taman. Madiun dengan jumlah guru mencapai ratusan. Lembaga ini cukup potensial dan strategis dalam membangun akhlak generasi penerus bangsa melalui pendidikan karakter. Kita ketahui bersama, guru dan orang tua adalah pendidik utama bagi anak, sehingga harus mempunyai wawasan luas serta menguasai metode pengasuhan anak secara benar. Selain itu upaya membangun generasi emas bagi bangsa Indonesia perlu mendapatkan dukungan dan aksi nyata dari berbagai pihak termasuk di dalamnya komponen pendidikan tinggi yang mempunyai banyak SDM unggul yang dapat dimanfaatkan untuk pemberdayaan masyarakat. Berdasarkan permasalahan di atas, maka untuk meningkatkan kualitas dan kapasitas guru TPQ-TPA perlu dilakukan pembekalan tentang karakter anak meliputi pemahaman permasalahan umum tentang peramutan anak dan permasalahan yang dihadapi saat ini, dasar karakter dan membangun komunikasi dengan anak serta tenik pengaliran karakter di kelas-kelas TPA. Dengan program ini diharapkan adanya peningkatkan wawasan dan kemampuan guru dalam mendidik para santri, meningkatkan kapasitas lembaga pendidikan Al Qur'an serta meningkatkan peran perguruan tinggi dalam membangun karakter di masyarakat.

\section{METODE KEGIATAN}

Kegiatan dilakukan melalui beberapa metode yaitu : Kegiatan dilakukan melalui beberapa metode yaitu :

1. Ceramah, untuk membuka wawasan dan menambah pengetahuan tentang pentingnya pembinaan karakter bagi anak usia dini.

2. Diskusi untuk pendalaman materi berdasarkan pengalaman nyata yang dihadapi orang tua dalam mendidikan anak.

3. Konsultasi Bimbingan konseling bagi orang tua yang menghadapi masalah khusus.

\section{HASIL DAN PEMBAHASAN}

\section{A. Permasalahan Yang dihadapi Orang Tua}

Pada umumnya orang tua mengeluh dan prihatin serta penuh kekhawatiran berkaitan dengan kondisi generasi remaja saat ini. Pengaruh kemajuan teknologi dan informasi digital khususnya HP telah merubah segalanya. Beberapa permasalahan dominan saat ini antara laian :

1. Karakter sopan santun telah luntur. Remaja sekarang dinilai sangat kurang dalam hal nilai-nilai dan norma dalam berperilaku dan berbicara. Kemampuan berbahasa yang baik sangat rendah, budaya antri tidak tertanam lagi, dan banyak lagi.

2. anak kurang menghargai orang tua dan guru. Anak sekarang pada umumnya kurang menghargai guru dan orang tua, suka membantah, berani dengan orang tua dan guru, bahkan berani melecehkan.

3. Pengaruh pergaulan bebas. Orang tua sangat khawatir dengan pergaulan remaja saat ini, yang sangat bertentangan dengan nilai moral dan agama. Pelajaran moral dan agama yang diberikan di sekolah seolah tidak membekas sama sekali.

4. anak kurang mandiri. Kemandirian anak sejak kecil sangat rendah, selalu tergantung kepada orang lain khususnya kepada orang tua.

5. Kualitas iman dan taqwanya sangat rendah. Anak hanya menjadikan agama sebagai pengetahuan mendapatkan nilai sekolah, bukan untuk pengamalan.

Guru dan orang tua semakin bingung karena tidak pernah mendapatkan wawasan ilmu tentang metode peramutan anak secara benar. Rata-rata mereka mendidik secara otodidak dan berdasarkan pengalaman, hanya sebagian kecil khususnya dari kalangan pendidik yang berkemampuan mendidik dengan baik dan mendekati benar.

\section{B. Analisis}

Berbagai permasalahan di atas, merupakan masalah umum dihadapi orang tua di seluruh dunia. Telah banyak kajian tentang masalah ini yang melahirkan berbagai metode pengasuhan anak secara benar. Ilmu agama, Pancasila dan ilmu moral lainnya yang diberikan di sekolah terbukti tidak mampu menjamin seseorang dapat berperilaku sesuai dengan standar moral yang diketahuinya ( Megawangi, 2017). Disebutkan lebih lanjut bahwa upaya membangun akhlak sulit dilakukan selama mengabaikan aspek emosi dalam diskursus yang berkaitan dengan masalah pengasuhan dan pendidikan anak. Tidak disadari bahwa selama ini pola pengasuhan anak banyak menanamkan emosi negative seperti rasa amrah, egois, dengki, iri hati dan lainlain yang terbawa pada diri anak sampai dewasa dan menjadi karakter yang sulit dihilangkan.

\section{Peran keluarga dalam membentuk Karakter}

\section{Fungsi keluarga}

Keluarga merupakan fondasi utama dalam bangunan masyarakat, bangsa dan Negara. Paling tidak ada lima nilai yang harus ditanamkan pada keluarga : cita kasih-sayang, komitmen, responsive, komunikasi dan kepedulian. Terpuruknya bangsa sebenarnya merupakan cerminan tidak berfungsinya keluarga dalam menyiapkan generasi penerus. Nilai cinta kasih sayang, komitmen, tanggung jawab, saling menghormati, kebersamaan dan komunikasi harus dibangun dalam keluarga. Kita ketahui 
Website : http://dayamas.unmermadiun.ac.id/index.php/dayamas

bersama bahwa anak usia dini dimana merupakan saat-saat strategis membentuk karakter, sebagian besar waktunya adalah di rumah. Dengan demikian peran orang yang di rumah khususnya orang tua akan sangat menentukan karakter anak ke depannya.

Setiap anggota keluarga tentunya mempunyai tanggung jawab bersama khususnya bapak dan ibu. Penanaman nilai karakter harus dimulai sejak anak lahir, sejak bayi harus mendapatkan kasih saying dan perhatian yang besar. Peran ibu sangat besar, sehingga ibu harus cerdas dan berwawasan luas serta selalu harus belajar.

Akibat buruk dari keluarga yang tidak menanamkan nilai-nilai luhur kepada anak anak dapat berakibat fatal. Anak tidak menguasai nilai baik dan buruk, tidak dapat berhubungan dengan orang lain, dan tidak akan efektif sebagai anggota masyarakat. Mal praktek oleh orang tua dan guru sangat berbahaya karena melahirkan generasi yang membawa kerusakan.

\section{Peran Lembaga Pendidikan}

Paradigma pendidikan dan pendidik sepertinya harus diubah. Muatan akademis yang mengarah pada pengasahan otak kiri yang saat ini sangat mendominasi kurikulum, perlu lebih banyak diimbangi muatan modal social, emosi, spiritual yang merupakan kinerja otak kanan. Kapasitas pendidik tentunya merupakan factor penentu, sehingga system pendidikan keguruan harus lebih banyak menyampaikan muatan karakter, sehingga guru/pendidik/ustadz/ustadzah dapat menanamkan nilai-nilai karakter, mempraktekkan sekaligus meneladani kepada anak didiknya. Guru tingkat PAUD dan Dasar, lebih ditekankan lagi dalam penanaman karakter anak karena usia PAUD dan SD adalah usia dimana 90\% otaknya berkembang pada usia ini. Dengan demikian guru, pendidik serta siapapun yang mengabdi pada pendidikan usia dini harus paham betul bagaimana mengasuh dan mendidik karakter anak. Kesalahan dalam mendidik pada usia ini akan menjadi mal praktek pendidikan yang berakibat berkepanjangan di usia selanjutnya.

\section{E. Pentingnya interaksi guru dan orang tua.}

Mendidik karakter anak, memerlukan konsistensi tinggi sehingga anak menerapkan karakter dimanapun berada. Karakter bukanlah sekedar teori/pengetahuan, namun harus praktek langsung. Sekolah tidak mungkin bisa banyak mempraktekkan karakter karena keterbatasan waktu di sekolah. Sebaliknya di rumahlah anak banyak memiliki waktu, sehingga orang tua dan penghuni rumah yang banyak berperan. Karenanya komitmen antara sekolah dengan orang tua sangatlah penting agar anak mendapatkan pola pengasuhan yang searah.
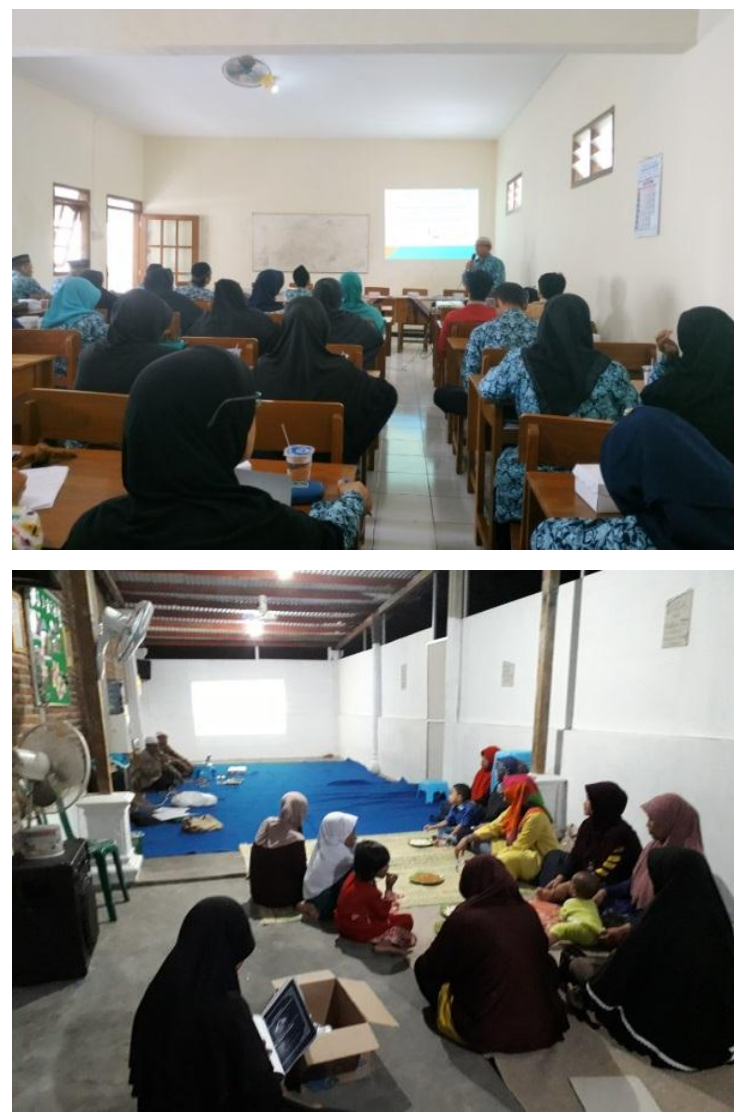

Gambar 1. Suasana pembekalan di FOSI dan di salah satu TPA 
Website : http://dayamas.unmermadiun.ac.id/index.php/dayamas

\section{KESIMPULAN}

Pendidikan karakter harus diterapkan sejak usia dini, karena pada usia tersebut perkembangan otak adalah paling maksimal. Pendidik pada usia itu yang terdiri guru TK, guru SD, guru TPA/TPQ dan lebih utama orang tua harus berwawasan luas tentang pendidikan karakter anak, serta dapat menjadi teladan bagi anak-anaknya.

\section{UCAPAN TERIMA KASIH}

Terima kasih penulis sampaikan kepada Rektor Unmer Madiun, Ketua FOSI Kecamatan Taman Kota Madiun serta segenap ustaz-ustadzah yang telah mengikuti kegiatan ini.

\section{VI.DAFTAR PUSTAKA}

Megawangi R, 2017. Menyemai Benih Karakter. Indonesia Heritage Foundation. Bogor.

Megawangi R, 2017. Gagal Membentuk Karakter ?, Mari Perbanyak Emosi Positip.

Lickona T, 2012. Educating for Character. Bumi Aksara, Jakarta.

http://paudjateng. blogspot.com. Membangun Karakter Anak Usia Dini. Unduh 9 Mei 2019.

Fitria N, 2017. Konsep Pendidikan Karakter Menurut Thomas Lickona Dan Yusuf Qardhawi(Studi Komparatif Tentang Metode, Strategi Dan Konten). Tesis. Fakultas Ilmu Tarbiyah dan Keguruan UIN Sunan Kalijaga. Yogyakarta. 